\title{
THE RESOURCE BASE OF US MILITARY TOURISM AND ITS REGIONAL FEATURES (CASE STUDY: MEMORIES OF THE WAR FOR INDEPENDENCE AND THE CIVIL WAR).
}

\begin{abstract}
The article unfolds the peculiarities of resource base of military tourism (case study: the USA), in particular, the military-historical tourist objects connected with the American War for Independence and the Civil War. The division of military tourism into such subspecies as military and historical, armored, military-tourism, military-historical festivals and reconstructions has been described. The list of countries of the world - the leaders on the number of tourist arrivals and the volume of tourism revenues and the place of the USA in this register has been given. The following features of the US military-historical tourist objects associated with the War of Independence (1775-1783) have been revealed: the Washington Monument, the mansion of the first US president "Mount Vernon", the Yorktown Battle Museum and the Victory Center, the National Military Historical Park "Saratoga", National Military History Park "Gilfort Courthouse", US Military Academy "West Point". The following Civil War-related (1861-1865) military-historical tourist sites have been named: the Lincoln Memorial, the National Museum of the Civil War of the United States, the National Monument "Fort Sumter", the National Military Park "Shailo", the Museum Battle of Antietam, Vicksberg National Military Park, Petersberg Museum of Fight, Gettisberg National Historical Park. The regional features of the US military tourism resource base in the seventeenth and nineteenth centuries have been analyzed. The results of the analysis are summarized in the table, which states that the objects of the resource base of tourism related to the War of Independence are concentrated in four US states, namely, Virginia (2), New York (2), the Federal District of Columbia (1) and North Carolina (1).
\end{abstract}

Key words: military tourism, resource base, USA, the War for Independence, the Civil War.

\section{УДК 327.88}

http://doi.org/10.17721/2521-1706.2018.04.198-207

Natalia Yakovenko, Dr. habil. (history), Professor, Institute of International Relations, Taras Shevchenko National University of Kyiv Galyna Piskorska, Senior Research Fellow, Institute of International Relations, Taras Shevchenko National University of Kyiv

\section{THE STRATEGIC COMMUNICATIONS OF THE USA}

\begin{abstract}
The article is aimed at tracing the role and effectiveness of the strategic communications of the United States in defending its geopolitical interests. The problem of strategic communications, as the authors say, has become popular in the world over the past two decades. It is mainly considered in the United States in scientific, political and commercial circles. The American political elites constantly adhere to their practical dominant: under every condition to preserve America's strategic leadership and expand the range of those states considering American model of development to be the most optimal for their own policies. According to official documents of the Ministry of Defense, State Department and other US government agencies, many attempts were made to provide a comprehensive and systematic assessment of the significance of strategic communications in foreign policy and ensuring the country's national security. It is stressed that to implement strategic communication in the world,
\end{abstract}


the United States has a number of competitive advantages. Among them it is worth to distinguish the following: the continuing economic, military and scientific predominance of the United States in the modern world; the global system of controlled military-political and economic unions, transnational institutions; the predominance in the sphere of mass culture over the cultural influence of other powers; superiority in the global media over any other country in the world; excellence in the theoretical and practical development of the national concept of strategic communications.

Keywords: strategic communications, USA, information opposition, public diplomacy, public relations.

The problem of strategic communications has become popular in the world over the past two decades. It is mainly considered in the United States in scientific, political and commercial circles. According to Ukrainian analysts, the concept of strategic communications is increasingly beginning to appear in regulatory and analytical documents of various levels in Ukraine as well [1].

From the beginning of the XXI century, in the United States, many attempts were made to provide a comprehensive and systematic assessment of the significance of strategic communications in foreign policy and ensuring the country's national security. Here you can refer to both relevant scientific research [2] and to a great amount of documents of the Ministry of Defense, State Department and other US government agencies [3].

The most common definition of strategic communications characterizes them as purposeful communications carried out by the organization to fulfill its mission. Strategic communications integrate all types of communication activities to secure the mission and provide sustainability of the organization. In turn, the meaning of strategic communications is to exert a targeted influence on key audiences related to the company's activities. It should be noted that American experts clearly define the place of strategic communications in the overall system of national security and closely associate it with the security and defense sector of the state.

Definition of strategic communications is contained in the report of the White House to the US Congress of March 16, 2010 on "National Framework for Strategic Communication" [4] which reflects an official approach to understanding this problem at the presidential level, and therefore has a direct impact on the external strategic communications of the United States.

"We refer to 'strategic communication (s)':

(a) the synchronization of words and deeds and how they will be perceived by selected audiences, as well as (b) programs and activities that are consciously aimed at communicating and engaging target audiences, including public diplomacy and information operations through public relations" [4, P. 2].

The need for a new approach to the communication of official structures arose as a result of the fact that after the terroristic attacks of September 11, 2001, the West once lost a communicative struggle against terrorists and insurgents. It was realized that the communicative activity of official structures is predominantly limited with a reaction to the propaganda of the enemy.

J. Bush, Jr., speaking on March 16, 2006 with the presentation of the new National Security Strategy of the USA, spoke for the priority of 'hard force' in the foreign policy of the state. In particular, he stressed that "America is in a state of war, so the strategy of national security in wartime is caused by the serious challenge we face - the spread of 
terrorism with its aggressive ideology of hatred and murder, which fully manifested itself to the American people on September 11, 2001" [5].

At the same time, the Strategy also contains key elements of soft power, such as the protection of freedom, democracy and human dignity throughout the world, to which the whole range of international political activity of the United States is involved; promotion of freedom as an alternative to authoritarianism and the maintenance of effective democracies; prevention of the proliferation of dangerous weapons, including high-tech, informational ones; stability of relations with the main powers of the world; support for global economic development in the context of transforming the global economic system, ensuring international peace and stability through the rule of law and the global leadership of America.

The pragmatic approach was to apply all possible mechanisms that would stabilize the situation in the world and ensure the further development of the American political system and economic progress [6].

It should be mentioned that during the first term of his presidency, George W. Bush's 'hard power' approach turned out to be false, and was revised during the second term of his presidency in favor of the principles of public diplomacy.

In the United States, there is an old tradition of influencing the peoples of other countries through public diplomacy. Unlike public relations, aimed primarily at informing and influencing the US public and media, public diplomacy includes efforts to directly interact with citizens, public figures, journalists and other public opinion leaders outside the country. Public diplomacy is designed to influence the attitude to the policy and national interests of the United States, to encourage actions in their support throughout the world [7, P. 1].

American public diplomacy includes such methods of influencing foreign societies as information programs, educational exchange, projects in the field of culture and sport, as well as digital diplomacy. Public diplomacy was not only actively used in all areas of foreign policy, but was thoroughly modified during B. Obama's presidency.

Elements of political technologies, propaganda, political communication, largescale use of social networks have forever changed traditional mechanism of public diplomacy. Personal influence of the President and his experts, new challenges in the international arena, new information technologies turned out to be so strong that the term of 'public diplomacy' was replaced by the term of 'strategic communication' in official US documents, which implies the priority of information campaigns over traditional programs of public diplomacy, and response information reaction to offensive propaganda by opponents.

All three main parts of strategic communications (public relations, public diplomacy and information operations) are interrelated, but they have their own peculiarities. Public diplomacy is defined as an instrument of US foreign policy and national security by influencing and establishing partnerships with the foreign public through exchange programs, training, sports, culture and information. Strategic communication is defined as the promotion of national interests of the United States through information, understanding of foreign audience requests and communication.Strategic communication suggests an emphasis on information tools for involving foreign public into the American agenda.

The essence of strategic communications lies in the fact that messages formulated for different target audiences do not conflict with each other. Strategic communications which are not limited by one specific audience are considered to be effective, but take 
into account the probable effects of the perception of a specific message by all other possible target audiences. Strategic communications are aimed at undermining and delegitimizing the enemy in the form of gaining support and recognition from the local population, electorate of their country, international community and all other target groups. Thus, the outcome of conflicts depends not only on whose army will win, but also on whose history will win. These ideas have become widespread in military thought and practice [8].

The military realized that the real results of tactical operations are less important than what the local population thinks about them. Consequently, the content core of strategic communications is the formation of [strategic] narrative - a convincing plot line which can explain events reasonably and from which conclusions can be drawn concerning reasons for the state's participation in the conflict, the significance of this situation and the prospects for the state in case of successful conflict resolution [9].

In the Joint Doctrine of Information Operations of Joint Chiefs of Staff (February 2006), the following definition of information operations is given:'Information operations (IO) are an integral part of the successful completion of military operations. The main objective of the IO is to achieve and maintain the information superiority of the United States and its allies. Information excellence provides united forces a competitive advantage only when it is effectively manifested in relevant decisions. IOs represent the integrated use of radioelectronic warfare, computer network operations, psychological operations, military deception and operational security, including their concomitant and applied aspects, in order to interfere, destroy, spoil or intercept the process of human or automated decision-making by the adversary, while protecting ourselves" [10, P. 1].

It is easy to see that strategic communications in the foreign policy sphere are the synchronization of the impact on friends and allies and the diverse spectrum of communications use within the framework of information confrontation. In today's world, experts note, the boundaries between war and peace, military and civilian systems and spaces, and between information and influence / manipulation are increasingly blurred.These changes naturally raise the question of new ways to protect society $[11, \mathrm{P}$. 629-646].

The spread of the battlefield to the human consciousness took place before as well. However, the professional conduct of combat in the minds and subconsciousness of people, using sophisticated methods of communication influence at the global level, with massive immersion of an increasing part of humanity into the virtual world of the Internet, social networks, allows to develop new types of information impact. Experts argue that today the effectiveness of communication is achieved only when the government (in this case the US Administration) preliminarily studies the signals and assessments coming from the foreign society. Such work is a process of 'listening' to opinions broadcast by the opposite side. This is followed by a reaction in the form of information campaigns aimed at correcting the image in a foreign society and a dialogue with those who make both negative and approving judgments [12, P. 123-139].

It should be noted that B. Obama defined the information sphere as an integral part of the national security and defense of the United States, emphasizing, first of all, the cybersecurity, which was considered the highest priority of the XXI century. Therefore, he contributed to coordinating the efforts of all federal agencies to implement a truly national cybersecurity policy, and proposed specific real recommendations formulated in officially published documents. In particular, B. Obama involved not only state structures, but academic circles and private sector specialists in the development of new 
standards and decisions on information security issues, considering that computer networks and infrastructure are strategic assets of the country, the security of which depends on the security of effective public administration and the livelihood of American society. Therefore, he said that national security needs to combine the efforts of the state, industry and academic circles that can best protect the infrastructure supporting economy and called for the development of new security standards to protect critical infrastructure elements. To this end, B. Obama, as the US President, supported funding for a number of research projects on the development of new technologies and information security tools using the created 5-billion-dollar fund aimed at the realization of state security under conditions of digital revolution [13].

From the point of view of B. Obama, the new US information security strategy also required joint activities of all governmental bodies dealing with information security issues, including the appointment of a new information security advisor as a member of the new Administration. This position was still under Presidents B. Clinton and J. Bush, Jr., but the last advisor left the Administration of J. Bush, accusing it of inactivity, since J. Bush, Jr., was never interested in issues of information and communication technologies.

In the speeches of B. Obama, the idea was expressed concerning the strategic nature of the digital infrastructure: "Our digital infrastructure is a strategic national asset whose protection is a priority of national security, which should be carried out taking into account confidentiality and civil freedoms". Through the Internet, B. Obama called on politicians and the whole American community to unite in actions to transform America into a leading world state, taking into account its political, economic, technological and social power [14].

An important project of the Obama Administration and his Secretary of State, $\mathrm{H}$. Clinton, was establishment of a dialogue between representatives of Google, Facebook, Twitter etc. and foreign activists, politicians, journalists and oppositionists. The project called TechCamp/Civil Society 2.0 is workshops where representatives of foreign nongovernmental organizations learn first-hand how to use the Internet when network access failed, how to hold information campaigns, and so on [15].

This project became one of the main results of Secretary of State Hillary Clinton's work, who has always been actively interested in using the US information resource in international politics. In her correspondence, there are a lot of letters from assistants with a detailed description of the development of the program in different countries. For example, at our disposal it is the description of seminars in Kyiv in 2012, which gathered over a hundred leaders of civil society from Belarus and Ukraine. This description presents the following skills acquired by political activists during seminars: using Facebook to conduct information campaigns and gain new supporters, attracting users of social networks to implement new political and social projects, creating videos to attract new supporters, creating websites for non-governmental organizations and promoting social reform projects [16].

As a result, public diplomacy in the form of social networks received a tool for the information impact of the United States on the political situation in foreign countries. Barack Obama radically changed the vector of public diplomacy: communication moves from the US government to a foreign blogger, bypassing the governments of foreign countries. However, mobilization of the opposition with the help of digital diplomacy has another side - revolutions, civil wars and radicalization of the opposition itself. The legacy of Obama's digital diplomacy remains in the laws on financing US foreign policy. 
A separate article on the protection of Internet freedom requires the subsequent White House Administrations to allocate $\$ 50$ million in direct dialogue with democratic elements in other countries [17].

The culmination of the use of strategic communication was the change in the Law on US foreign policy information activities. The 1994 Law proclaimed freedom to provide information concerning US foreign policy through such channels as Voice of America, Radio Marti, Radio Free Europe, and others.

In April 2014, the US Congress proposed to change the 1994 Law in order to expand the propaganda of the interests of US government. Tense situation in the world and the aggravation of the information confrontation inside the US itself during 2016 presidential election campaign convinced President of the need to subordinate all US information channels to a unified strategy of US foreign policy. Barack Obama agreed to congressmen's offer, and the Republicans introduced a provision in the bill that the future President will appoint the Head of the Broadcasting Board of Governors (BBG), to which all information activities of the United States in foreign countries are subordinated. Previously, this position was elective and was controlled by the two-party council, which allowed 'diversify' of information flow [18].

Assuming the victory of $\mathrm{H}$. Clinton, B. Obama, signing this Law seemed to only strengthen the policy of strategic communication of the United States. However, the election of D. Trump put the democratic Administration in a difficult situation, since the new rule concerning management of all US international information resources gives legal authority to President D. Trump to appoint the Head of the Office a person under control of the President.

The aggregate audience of the US international information resources reaches 215 million people around the world during a week. According to the BBG Chairman, new Executive Director "understands that the transfer and critical assessment of the US official policy is a key component of the BBG mission. The US leading role in the world depends in part on whether the international audience knows about the position of the United States regarding different countries and various problems that affect them" [19].

To implement strategic communication in the world, the United States has a number of competitive advantages. Among them it is worth to distinguish the following:

- The continuing economic, military and scientific predominance of the United States in the modern world;

- The global system of controlled military-political and economic unions, transnational institutions;

- The predominance in the sphere of mass culture over the cultural influence of other powers;

- Superiority in the global media over any other country in the world;

- Excellence in the theoretical and practical development of the national concept of strategic communications.

\section{Література}

1. Баровська А. В. Стратегічні комунікації: досвід НАТО / А. В. Баровська // Стратегічні пріоритети. - 2015. - № 1 (34). - С. 147-151; Гуцал С. А. Публічна дипломатія та стратегічні комунікації: визначення концептуальних основ [Електронний ресурс] - Режим доступу: http://journals.iir.kiev.ua/index.php/pol_n/article/viewFile/2769/2473 (Дата звернення: 10 вересня 2017) - Назва з екрану; Дубов Д. Стратегічні комунікації: проблеми концептуалізації та практичної реалізації [Електронний ресурс] - Режим доступу: http://ippi.org.ua/sites/default/files/dubov.pdf. (Дата звернення: 10 вересня 2017) - Назва з екрану; Ліпкан В. А. Роль стратегічних комунікацій в протидії гібридній війні проти України [Електронний ресурс]. - Режим доступу: 
http://goalint.org/rol-strategichnix-komunikacij-v-protidii-gibridnij-vijni-proti-ukraini/ (Дата звернення: 10 вересня 2017) - Назва з екрану; Почепцов Г. Г. Стратегічні комунікації: стратегічні комунікації в політиці, бізнесі та державному управлінні / Г.Почепцов. - К.: Альтерп- рес, 2008. - 216 с.; Соловйов С. Г. Основні характеристики стратегічних комунікацій [Електронний ресурс] - Режим доступу :http://nuczu.edu.ua/sciencearchive/PublicAdministration/vol4/24_2016.pdf - (Дата звернення: 10 вересня 2017) - Назва з екрану.

2. Abraham A. J. The Strategic Communications Process - How to Get Our Message Out More Effectively / A. J. Abraham. - Washington: National Defense University, NationalWarCollege Paper. 2004. - 244 p.; Arquilla J. Information Strategy and Warfare / A Guide to Theory and Practice / J. Arquilla, D. A. Border. - New York - London: Routletge, 2007. - 248 p.; Holtzhausen D. The Routledge Handbook of Strategic Communication / D. Holtzhausen, A.Zerfass. - New York and London, 2015. - 63 p.

3. Handbook for Strategic Communication and Communication Strategy. Version 3.0. - Unites States Joint Forces Command. - 2010. - Suffolk : WarfightingCenter. - June 24. - 232 p.; National Framework for Strategic Communication. - Washington : White House Strategic Communications Report to Congress. - 2010. - March 17. - 16 p.; Report on Strategic Communication. Department of Defense. December 2009. - Washington, DC. The Secretary of Defense, 20301-1000. - Feb. 11, 2010; Strategic communications and the spectrum of conflict [Electronic Resource] - Mode of access: http://www.dtic.mil/dtic/tr/fulltext/u2/a488153.pdf(last access: September 10, 2017). - Title from the Screen; The President's National Framework for Strategic Communication (and Public Diplomacy) for 2012 [Electronic Resource] - Mode of access: https://mountainrunner.us/2012/03/national-frameworkstrategic-communication-public-diplomacy(last access: September 10, 2017). - Title from the Screen.

4. National Framework for Strategic Communication. - Washington: White House Strategic Communications Report to Congress. - March 17, 2010. - 16 p.

5. BushG. W. The National Security Strategy (March 16, 2006) [Electronic Resource] - Mode of access: http://www.presidentialrhetoric.com/speeches/03.16.06.html (last access: September 10, 2017). - Title from the Screen.

6. KrauthammerC. DemocraticRealism: AnAmericanForeignPolicyforaUnipolarWorld [Electronic Resource] - Mode of access: http://aei.org/docLib/20040227_book755text.pdf(last access: September 10, 2017). - Title from the Screen.

7. Nakamura K. H. U.S. Public Diplomacy: Background and Current Issues. CRS Report for Congress Prepared for Members and Committees of Congress / K. H. Nakamura, M. C. Weed. Congressional Research Service, 2009. - 65 p.

8. A National Strategic Narrative by MrY.WoodrowWilsonInternationalCenter for Scholars. Washington, DC, 2011. [Electronic Resource] - Mode of access: https://www.wilsoncenter.org/sites/default/files/A\%20National\%20Strategic\%20Narrative.pdf (last access: September 10, 2017). - Title from the Screen.

9. Neate Mark C. The Battle of the Narrative - Kansas : School of Advanced Military Studies United States Army Command and GeneralStaffCollegeFortLeavenworth, 2010. - 56 p. [Electronic Resource] - Mode of access: http://www.au.af.mil/au/awc/awcgate/sam/battle_of_narrative_neate.pdf (last access: September 10, 2017). - Title from the Screen.

10. Joint Doctrine for Information Operations. February 2006 / U.S. Department of Defense. Joint Chiefs of Staff. Joint Publications 3-13 [Electronic Resource] - Mode of access:URL://http://www.fas.org/irp/doddir/dod/jp3_13.pdf(last access: September 10, 2017). - Title from the Screen.

11. Brunner E. M. The Formation of Information by the US Military: Articulation and Enactment of Information Threat Imaginaries on the Immaterial Battlefield of Perception / E. M. Brunner, M. D. Cavelty // Cambridge Review of International Affairs. - 2009. - December. - P. 629-646.

12. Cull N. J. The long road to public diplomacy 2.0: the internet in us public diplomacy / N. J. Cull // International studies review. - 2013. - Vol. 15(1). - P. 123-139.

13. Barack Obama's speechatthe University of Purdue (July 16, 2008) / Barack Obama [Electronic Resource] - Mode of access: http://www.cfr.org/publication/16807/barack_obamas_speech_at_the_university_of_purdue.html(la st access: June 16, 2017). - Title from the Screen.

14. Remarks by the President in State of the Union Address (January 20, 2015) [Electronic Resource] - Mode of access:https://obamawhitehouse.archives.gov/the-press-office/2015/01/20/remarkspresident-state-union address-january-20-2015 (last access: June 16, 2017). - Title from the Screen. 
15. A Network of Ideas: TechCamp creates connections, sparks innovation, and empowers civil society to solve the world's most pressing challenges through technology [Electronic Resource] - Mode of access:https://techcamp.america.gov (last access: June 16, 2017). - Title from the Screen.

16. Techcamp in Kyiv: building a bridge between civil society and technology. A letter from Mills, Cheryl and Ross, Alec to Clinton, Hilary. Doc. No c05792554. [Electronic Resource] - Mode of access:URL: https://wikileaks.org/clintonemails/clinton_email_november_release/c05792554.pdf(last access: January 9, 2017). - Title from the Screen.

17. National defense authorization Act for fiscal year 2017. Public Law 114-328. [Electronic Resource] - Mode of access:URL:https://www.congress.gov(last access: January 9, 2017). - Title from the Screen.

18. BBG Watch-U.S. and International Media [ElectronicResource] - Mode of access: http://bbgwatch.com/bbgwatch (lastaccess: January10, 2017). - Title from the Screen.

19. Джон Лэнсинг назначен новым исполнительным директором Совета управляющих по вопросам вещания США [Електронний ресурс]. - Режим доступу: https://www.golosameriki.ru/a/cn-us-bbg-ceo/2922747.html (Дата звернення: 19 вересня 2017). - Назва з екрану.

\section{References}

1. BAROVS'KA, A. (2015) Stratehichni komunikatsiyi: dosvid NATO. Stratehichni priorytety. 1 (34), p. 147-151; Hutsal, S.A. Publichna dyplomatiya ta stratehichni komunikatsiyi: vyznachennya kontseptual'nykh [Online]. Avnov from: http://journals.iir.kiev.ua/index.php/pol_n/article/viewFile/2769/2473(Accessed: September 10, 2017); DUBOV, D. Stratehichni komunikatsiyi: problem kontseptualizatsiyi ta praktychnoyi realizatsiyi [Online]. Available from: http://ippi.org.ua/sites/default/files/dubov.pdf(Accessed: September 10, 2017); LIPKAN, V. Rol' stratehichnykh komunikatsiy $\mathrm{v}$ protydiyi hibrydniy viyni proty Ukrayiny [Online]. Available from: http://goalint.org/rol-strategichnix-komunikacij-v-protidii-gibridnij-vijni-protiukraini(Accessed: September 10, 2017); POCHEPTSOV, H. (2008) Stratehichni komunikatsiyi: stratehichni komunikatsiyi v politytsi, biznesi ta derzhavnomu upravlinni. Kyiv: Al'terpres; SOLOVYOV, S. Osnovni kharakterystyky stratehichnykh komunikatsiy [Online]. Available from: http://nuczu.edu.ua/sciencearchive/PublicAdministration/vol4/24_2016.pdf (Accessed: September 10, 2017).

2. ABRAHAM, A. (2004) The Strategic Communications Process - How to Get Our Message Out More Effectively. Washington: National Defense University, National War College Paper; ARQUILLA, J., BORER, D. (2007) Information Strategy and Warfare / A Guide to Theory and Practice. New York - London: Routletge; Holtzhausen, Derina, Zerfass, Ansgar (2015). The Routledge Handbook of Strategic Communication. New York and London.

3. Handbook for Strategic Communication and Communication Strategy (2010) Version 3.0. Unites States Joint Forces Command, Warfighting Center, Suffolk, June 24, 2010; National Framework for Strategic Communication (2010). Washington: White House Strategic Communications Report to Congress. March 17, 2010; Report on Strategic Communication (2009). Department of Defense. December 2009. The Secretary of Defense, Washington, DC, 20301-1000. Feb. 11, 2010; Strategic communications and the spectrum of conflict [Online]. Available from: http://www.dtic.mil/dtic/tr/fulltext/u2/a488153.pdf(Accessed: September 10, 2017); The President's National Framework for Strategic Communication (and Public Diplomacy) for 2012 (2012) [Online]. Available from: https://mountainrunner.us/2012/03/national-framework-strategic-communication-publicdiplomacy (Accessed: September 10, 2017).

4. National Framework for Strategic Communication (2010). Washington: White House Strategic Communications Report to Congress. March 17, 2010.

5. BUSH, G.W. (2006) The National Security Strategy (March 16, 2006).Washington, DC [Online]. Available from: http://www.presidentialrhetoric.com/speeches/03.16.06.html (Accessed: September 10, 2017).

6. KRAUTHAMMER,C. (2004) Democratic Realism: An American Foreign Policy for a Unipolar World. [Online]. Available from: http://aei.org/docLib/20040227_book755text.pdf (Accessed: September 10, 2017).

7. NAKAMURA, K.H., WEED, M.C. (2009) U.S. Public Diplomacy: Background and Current Issues. CRS Report for Congress Prepared for Members and Committees of Congress. Congressional Research Service.

8. A National Strategic Narrative by Mr Y. (2011) Woodrow Wilson International Center for Scholars. Washington, DC. [Online] Available from: 
https://www.wilsoncenter.org/sites/default/files/A\%20National\%20Strategic\%20Narrative.pdf (Accessed: September10, 2017).

9. NEATE, M. (2010) The Battle of the Narrative. School of Advanced Military Studies United States Army Command and General Staff College Fort Leavenworth. Kansas. [Online] Available from: http://www.au.af.mil/au/awc/awcgate/sam/battle_of_narrative_neate.pdf(Accessed: September10, 2017).

10. U.S. Department of Defense. Joint Chiefs of Staff. Joint Publications 3-13, Joint Doctrine for Information Operations (2006) [Online] Available from: URL://http://www.fas.org/irp/doddir/dod/jp3_13.pdf (Accessed June 16, 2017).

11. BRUNNER, E.M., CAVELTY, M.D. (2009) The Formation of Information by the US Military: Articulation and Enactment of Information Threat Imaginaries on the Immaterial Battlefield of Perception. Cambridge Review of International Affairs. December, p. 629-646.

12. CULL, N. J. (2013) The long road to public diplomacy 2.0: the internet in us public diplomacy. International studies review. 15(1), p. 123-139.

13. Barack Obama's speech at the University of Purdue (2008)[Online]. Available from: http://www.cfr.org/publication/16807/barack_obamas_speech_at_the_university_of_purdue.html(A ccessed June 16, 2017).

14. Remarks by the President in State of the Union Address (2015) [Online]. Available from: https://obamawhitehouse.archives.gov/the-press-office/2015/01/20/remarks-president-state-unionaddressjanuary-20-2015 (Accessed June 16, 2017).

15. A Network of Ideas: TechCamp creates connections, sparks innovation, and empowers civil society to solve the world's most pressing challenges through technology[Online]. Available from: https://techcamp.america.gov(Accessed June 16, 2017).

16. Techcamp in Kyiv: building a bridge between civil society and technology. A letter from Mills, Cheryl and Ross, Alec to Clinton, Hilary. Doc. No c05792554 (2016) [Online] Available from: URL: https://wikileaks.org/clintonemails/clinton_email_november_release/c05792554.pdf (Accessed January 9, 2017).

17. National defense authorization Act for fiscal year 2017. Public Law 114-328. U.S. Congress (2016) [Online] Available from: URL: https://www.congress.gov/(Accessed January 9, 2017).

18. BBG Watch-U.S. and International Media [Online]. Available from: http://bbgwatch.com/bbgwatch (Accessed $10^{\text {th }}$ January 2017).

19. Dzhon Lensing naznachen novym ispolnitel'nym direktorom Soveta upravlyayushchikh po voprosam veshchaniya SSHA [Online]. Available from: https://www.golos-ameriki.ru/a/cn-us-bbgceo/2922747.html(Accessed 19 $9^{\text {th }}$ September 2017).

Надійшла до редколегії 19.09.2017

Наталія Яковенко, доктор історичних наук, професор кафедри міжнародних організацій і дипломатичної служби ІМВ КНУ імені Тараса Шевченка, Київ

Галина Піскорська, кандидат історичних наук, доцент, старший науковий співробітник IМВ КНУ імені Тараса Шевченка, Київ

\section{СТРАТЕГІЧНІ КОМУНІКАЦІЇ США}

Автори статті ставлять за мету відстежсити роль та ефективність стратегічних комунікацій Сполучених Штатів у відстоюванні своїх геополітичних інтересів. Американський політикум завжди чітко дотримується практичної домінанти: за будь яких обставин, всіма можливими засобами зберегти стратегічне лідерство Америки і розширити коло краӥн, які вважають американську модель розвитку найоптимальнішою для власної політики. Автори зазначають що з початку XXI cm. в США мало місие багато спроб дати різнобічну $i$ системну оцінку значущості стратегічних комунікацій у зовнішній політиці і забезпеченні національної безпеки країни, посилаючись на відповідні наукові дослідження $i$ на великий пласт документів Міністерства оборони, Державного департаменту та інших державних структур США. Наголошується, щуо для здійснення стратегічної комунікації в світі США мають у своєму розпорядженні цілу низку конкурентних переваг. Серед них слід зазначити: наявне економічне, військове і наукове переважання США в сучасному світі; глобальну систему 
підконтрольних військово-політичних $i$ економічних союзів, трансначіональних інститутів; перевагу в сфері масової культури над культурним впливом інших держав; перевагу в глобальних ЗМІ над будь-якою іншою країною світу; перевагу в теоретичній $i$ практичній розробиі національної концепчії стратегічних комунікацій.

Ключові слова: стратегічні комунікащії; США; информачійне протистояння; публічна дипломатія; зв'язки з громадськістю. 